\title{
Oxidation of Plasma Free Fatty Acids in Nonshivering Thermogenesis of Rats Treated Chronically with Norepinephrine and Thyroxine*
}

\author{
Kiyoshi Moriya, Miya Kobayashi,** and Tsutomu Hiroshige*** \\ Laboratory of Health Education, Faculty of Education, Hokkaido University, \\ **Department of Anatomy, Hokkaido University of Dentistry, \\ ***Department of Physiology, Hokkaido University School of Medicine, \\ Sapporo, Hokkaido, 060 Japan
}

\begin{abstract}
In rats treated chronically with norepinephrine and thyroxine, enhanced nonshivering thermogenesis was observed, with a concomitant increase in the utilization of plasma free fatty acids (FFA). The increased utilization of plasma FFA was characterized by a more preferential increment in the oxidation of FFA in tissues rather than that in the uptake of FFA by tissues. These biochemical findings were accompanied by an increased mitochondrial mass in red fibers of skeletal muscle. Both biochemical and morphological changes of a similar nature were found in cold-acclimated rats.
\end{abstract}

Enhanced nonshivering thermogenesis (NST) is one of the characteristics of cold acclimation in small animals such as rats. In a previous study (MorIYA et al., 1977), we showed that an elevated NST in cold-acclimated animals is explicable more directly by an increase in oxidation of plasma free fatty acids (FFA), an important substrate for NST, rather than by an elevated uptake by tissues. Moreover, we showed in confirmation of an earlier report (LEBLANC and VILLEMAIRE, 1970) that chronic treatment of rats with norepinephrine and thyroxine resulted in simulation of cold acclimation: an increase in both NST and uptake of FFA was demonstrated in response to the infusion of norepinephrine, a major mediator of NST (MORIYA et al., 1975). In this study, the effects of norepinephrine and thyroxine on the enhanced utilization of FFA were estimated by simultaneous assessment of the uptake and oxidation of plasma FFA in rats. In addition, changes in mitochondria which are the intracellular site of FFA oxidation and respiration were studied. Changes in mitochondria of skeletal muscles have been observed in animals acclimated to cold (HIMMS-HAGEN et al., 1975; YAHATA and KUROSHIMA, 1977) and in animals treated chronically with thyroxine (GUSTAFSSON

Received for publication February 14, 1981

* The part of this work using radioisotopes was performed in the Central Institute of Isotope Science, Hokkaido University.

森谷 絜, 小林身哉, 広重 力 
et al., 1965) but so far not in animals treated chronically with norepinephrine.

\section{MATERIALS AND METHODS}

Animals and experimental design. Male Wistar rats aged 30 to 45 days were divided into the following five groups. The first group was a control in which rats were injected subcutaneously with an olive oil vehicle. The rats of the second group were injected with norepinephrine (NE) suspended in olive oil in a daily dose of $70 \mu \mathrm{g} / 100 \mathrm{~g}$ body weight (NE group). Rats of the third group were injected with thyroxine $\left(\mathrm{T}_{4}\right)$ in a dose of 3 or $5 \mu \mathrm{g} / 100 \mathrm{~g}\left(\mathrm{~T}_{4}-1\right.$ and $\mathrm{T}_{4}-2$ groups, respectively). Rats of the fourth group were injected with both $\mathrm{NE}$ and $\mathrm{T}_{4}$ simultaneously in doses of 35 and $2.5 \mu \mathrm{g} / 100 \mathrm{~g}$, respectively, or 47 and $3.4 \mu \mathrm{g} / 100 \mathrm{~g}$, respectively (NE+ $\mathrm{T}_{4}-1$ and $\mathrm{NE}+\mathrm{T}_{4}-2$ groups). The fifth group consisted of cold-acclimated rats exposed to a temperature of $5^{\circ} \mathrm{C}$. These treatments were continued for 4 to 6 weeks until the day before the experiment. The animals were provided with tap water and rat chow (Oriental MF, Oriental Yeast Co., Tokyo) ad libitum.

Estimation of rates of uptake and oxidation of plasma FFA in vivo. After $18 \mathrm{hr}$ fasting, rats were moved from the rearing rooms to an experimental room kept at a temperature of $25^{\circ} \mathrm{C} 1 \mathrm{hr}$ prior to anesthesia with pentobarbital $(70 \mathrm{mg} / \mathrm{kg}$ body weight, i.p.). $\quad \mathrm{CO}_{2}$ output as an indicator of thermogenesis was measured. Plasma FFA taken up by tissues and its oxidation were estimated using a constant intravenous infusion method; ${ }^{14} \mathrm{C}-1$-palmitate divided by the specific activity (SA) of FFA represented the rate of uptake of plasma FFA. The oxidation rate of FFA was calculated from respiratory $\mathrm{CO}_{2}$ output and the fraction of $\mathrm{CO}_{2}$ derived from the immediate oxidation of plasma FFA. To obtain the $\mathrm{CO}_{2}$ fraction, recovery of $\mathrm{NaH}^{14} \mathrm{CO}_{3}$ infused intravenously as ${ }^{14} \mathrm{CO}_{2}$ was estimated according to the procedures described in a previous study (MORIYA et al, 1977). Equations for calculating uptake and oxidation of plasma FFA are as follows:

(1) Uptake $(U)$ (=FFA produced and taken up by tissues $)(\mu \mathrm{Eq} / \mathrm{min})$

$$
\begin{aligned}
& U=\frac{I(\mathrm{nCi} / \mathrm{min})}{\mathrm{SA} \text { of FFA }\left(\mathrm{nCi}{ }^{14} \mathrm{C} / \mu \mathrm{Eq} \text { of FFA }\right)}, \\
& I: \quad \text { rate of }{ }^{14} \mathrm{C} \text {-palmitate infused intravenously. }
\end{aligned}
$$

(2) Oxidation $(O)(\mu \mathrm{Eq} / \mathrm{min})$

$$
\begin{aligned}
& O=F \times \text { total } \mathrm{CO}_{2} \text { output }(\mu \mathrm{mol} / \mathrm{min}) \times 1 / 17 \text {, } \\
& F \text { : fraction of } \mathrm{CO}_{2} \text { derived from the oxidation of } \mathrm{FFA} \text {, } \\
& F=\frac{\mathrm{SA}_{t=\infty} \text { of } \mathrm{CO}_{2}\left(\mathrm{nCi}^{14} \mathrm{C} / \mu \mathrm{mol} \text { of } \mathrm{CO}_{2}\right)}{\mathrm{SA} \text { of } \mathrm{FFA}\left(\mathrm{nCi}^{14} \mathrm{C} / \mu \mathrm{Eq} \text { of } \mathrm{FFA}\right)} \times 17, \\
& \mathrm{SA}_{t=\infty} \text { of } \mathrm{CO}_{2}=\frac{\text { measured } \mathrm{SA} \text { of } \mathrm{CO}_{2}}{\% \text { of } \mathrm{NaH}^{14} \mathrm{CO}_{3} \text { recovered as }{ }^{14} \mathrm{CO}_{2}} \times 100 \text {. }
\end{aligned}
$$

Electron microscopic study. The tissue blocks of diaphragm were fixed with $0.1 \mathrm{M}$ cacodylate-buffered $4 \%$ paraformaldehyde ( $\mathrm{pH} 7.4$ ) for 2 or 3 days and then 
fixed in $0.1 \mathrm{M}$ cacodylate-buffered $2 \%$ glutaraldehyde $\left(\mathrm{pH} 7.4\right.$ ) for $2 \mathrm{hr}$ at $4^{\circ} \mathrm{C}$ respectively. They were postfixed with $1 \%$ osmium tetroxide in $0.1 \mathrm{M}$ cacodylate buffer ( $\mathrm{pH} 7.4$ ) for $90 \mathrm{~min}$ at room temperature. After dehydration with graded ethanol, they were embedded in Epon-812. In transverse sections, red fibers were distinguished from white or intermediate fibers according to the histological characteristics described by GAUTHIER (1977). Ultrathin sections of the red fiber were cut on a Porter Blum MT-2 ultramicrotome using a glass knife. The sections were stained with uranyl acetate and lead citrate and examined in a Hitachi electron microscope (HU-11DS or 12A). The number of mitochondria was counted in an area, chosen at random, of the red fiber in the electron micrographs at a magnification of $\times 7,000$. At the same time, the size of the cross-sectional area of mitochondria was measured. Different portions of 6 to 12 red fibers were examined in each group.

Drugs. Norepinephrine bitartrate (Wako Chem. Co.) and sodium thyroxine (Wako Chem. Co.) were used. ${ }^{14} \mathrm{C}$-1-palmitate and $\mathrm{NaH}^{14} \mathrm{CO}_{3}$ were purchased from New England Nuclear Co.

Statistics. Student's $t$-test was used to determine the significance of differences between the means.

\section{RESULTS}

\section{Body weight changes}

Body weight was an average of $136 \mathrm{~g}$ at the beginning of the treatments. After the first 4 weeks, it increased from 126 to $284 \mathrm{~g}$ (percent increase: $261 \pm 17 \%$, mean \pm S.E., $n=15)$ in the controls; from 135 to $309 \mathrm{~g}(242 \pm 12 \%, n=12)$ in the $\mathrm{NE}$ group; from 159 to $353 \mathrm{~g}(229 \pm 15 \%, n=6)$ in the $\mathrm{T}_{4}-1$ group; from 123 to $310 \mathrm{~g}(270 \pm 16 \%, n=10)$ in the $\mathrm{T}_{4}-2$ group; from 132 to $287 \mathrm{~g}(227 \pm 11 \%, n=10)$ in the $\mathrm{NE}+\mathrm{T}_{4}-1$ group; from 156 to $330 \mathrm{~g}(212 \pm 6 \%, n=5)$ in the $\mathrm{NE}+\mathrm{T}_{4}-2$ group; and from 145 to $260 \mathrm{~g}(179 \pm 15 \%, n=12)$ in cold-acclimated rats. The increment in the cold-acclimated rats was significantly smaller than that in the controls.

\section{Thermogenic responses to norepinephrine infusion}

$\mathrm{CO}_{2}$ outputs in response to norepinephrine infusion at a rate of $2 \mu \mathrm{g} / \mathrm{min}$ for 20 min increased significantly in all groups (Table 1). $\mathrm{CO}_{2}$ output before norepinephrine infusion (initial $\mathrm{CO}_{2}$ outputs) in the $\mathrm{T}_{4}, \mathrm{NE}+\mathrm{T}_{4}$, and cold-acclimated groups were higher than that of the controls. Although no difference was observed in the initial $\mathrm{CO}_{2}$ outputs between the NE group and the controls, the net increase of the NE group was similar in magnitude to that of the cold-acclimated rats. The value after norepinephrine infusion in the $\mathrm{T}_{4}$ group was higher than in the controls, but the net increase in both groups did not differ. In the $\mathrm{NE}+\mathrm{T}_{4}$ group, incremental responses to norepinephrine higher than in the controls were observed and the net increases were similar in magnitude to the increase occurring with the cold-acclimated rats. 
Table 1. Effect of norepinephrine infusion ( $2 \mu \mathrm{g} / \mathrm{min}$ for $20 \mathrm{~min})$ on the respiratory $\mathrm{CO}_{2}$ outputs in rats treated chronically with norepinephrine (NE) and thyroxine $\left(\mathrm{T}_{4}\right)$ under pentobarbital anesthesia.

\begin{tabular}{lcllll}
\hline & $\begin{array}{c}\text { No. } \\
\text { of rats }\end{array}$ & Before & After & $\begin{array}{c}\text { Paired } \\
\text { difference }\end{array}$ & $P$ \\
\hline Controls & 15 & $20 \pm 2$ & $43 \pm 3$ & $23 \pm 3$ & $<0.001$ \\
NE group & 12 & $20 \pm 3^{*}$ & $72 \pm 6^{*}$ & $52 \pm 4$ & $<0.001$ \\
$P$ vs. controls & & $\mathrm{N} . \mathrm{S}$. & $<0.001$ & $<0.001$ & \\
$\mathrm{~T}_{4}-\mathbf{1}$ group & 6 & $33 \pm 2$ & $61 \pm 2^{*}$ & $28 \pm 2^{* *}$ & $<0.001$ \\
$\boldsymbol{P}$ vs. controls & & $<0.01$ & $<0.01$ & $\mathrm{~N} . \mathrm{S}$. & \\
$\mathrm{T}_{4}-2$ group & 10 & $35 \pm 5$ & $64 \pm 5^{* *}$ & $28 \pm 2^{* * *}$ & $<0.001$ \\
$\boldsymbol{P}$ vs. controls & & $<0.01$ & $<0.001$ & $\mathrm{~N} . \mathrm{S}$. & \\
$\mathrm{NE}+\mathrm{T}_{4}-1$ group & 10 & $40 \pm 3$ & $80 \pm 3$ & $40 \pm 4$ & $<0.001$ \\
$\boldsymbol{P}$ vs. controls & & $<0.001$ & $<0.001$ & $<0.01$ & \\
$\mathrm{NE}+\mathrm{T}_{4}-2$ group & 5 & $36 \pm 3$ & $85 \pm 6$ & $49 \pm 3$ & $<0.001$ \\
$\boldsymbol{P}$ vs. controls & & $<0.001$ & $<0.001$ & $<0.001$ & \\
Cold-acclimated & 12 & $31 \pm 4$ & $94 \pm 8$ & $63 \pm 7$ & $<0.001$ \\
$\boldsymbol{P}$ vs. controls & & $<0.05$ & $<0.001$ & $<0.001$ & \\
\hline
\end{tabular}

Means \pm S.E. of the mean, expressed as $\mu \mathrm{mol} /(\min \cdot 100 \mathrm{~g}$ body weight $) . \quad P$ values are given in the last column for the paired difference. ${ }^{*} P<0.05,{ }^{* *} P<0.01,{ }^{* * *} P<0.001 v$ s. cold-acclimated rats. N.S.: not significant. Each group was treated as described in the text.

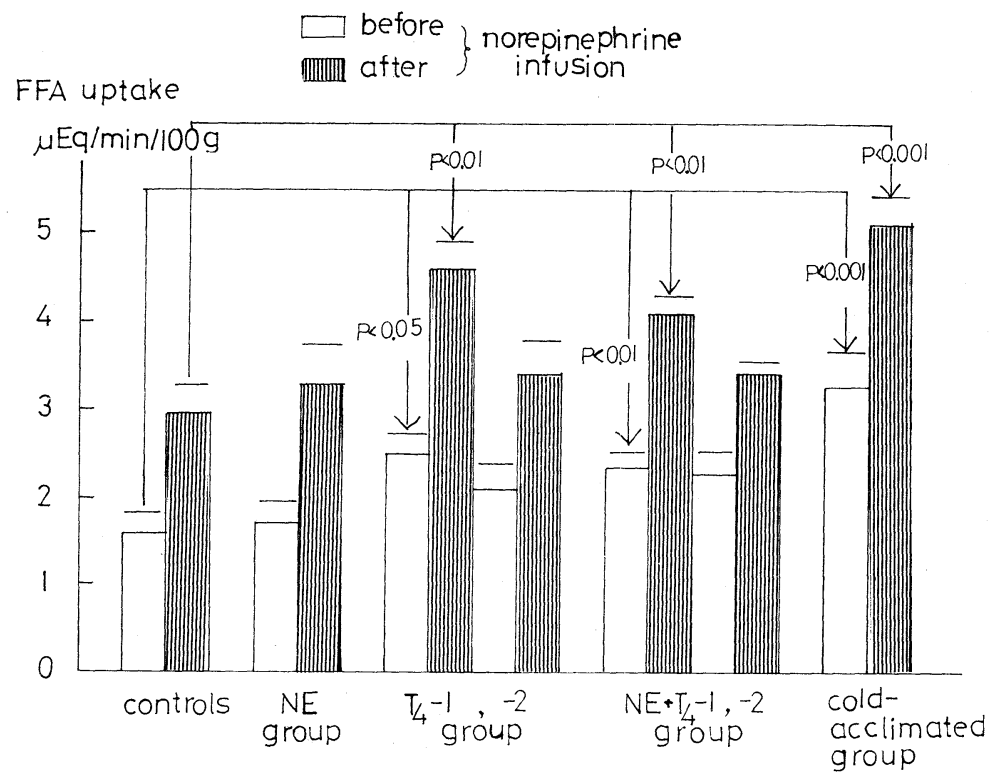

Fig. 1. Changes in plasma free fatty acids (FFA) taken up by tissues due to norepinephrine infusion at a rate of $2 \mu \mathrm{g} / \mathrm{min}$ for $20 \mathrm{~min}$. Bars on the tops of columns represent S.E. of the means. Each group was treated as described in the text. NE: norepinephrine. $\mathrm{T}_{4}$ : thyroxine. 
Table 2. Effect of norepinephrine infusion ( $2 \mu \mathrm{g} / \mathrm{min}$ for $20 \mathrm{~min}$ ) on the oxidation of plasma free fatty acids (FFA) in rats treated chronically with norepinephrine (NE) and thyroxine $\left(\mathrm{T}_{4}\right)$ under pentobarbital anesthesia.

\begin{tabular}{|c|c|c|c|c|c|}
\hline & $\begin{array}{l}\text { No. } \\
\text { of rats }\end{array}$ & Before & After & $\begin{array}{l}\text { Paired } \\
\text { difference }\end{array}$ & $P$ \\
\hline Controls & 15 & $0.09 \pm 0.01$ & $0.86 \pm 0.10$ & $0.77 \pm 0.09$ & $<0.001$ \\
\hline NE group & 12 & $0.14 \pm 0.02$ & $2.35 \pm 0.30$ & $2.21 \pm 0.25$ & $<0.001$ \\
\hline$P$ vs. controls & & $<0.05$ & $<0.001$ & $<0.001$ & \\
\hline $\mathrm{T}_{4}-1$ group & 6 & $0.20 \pm 0.02$ & $2.06 \pm 0.23$ & $1.83 \pm 0.18$ & $<0.001$ \\
\hline$P$ vs. controls & & $<0.001$ & $<0.001$ & $<0.001$ & \\
\hline $\mathrm{T}_{4}-2$ group & 10 & $0.28 \pm 0.07$ & $2.17 \pm 0.33$ & $1.89 \pm 0.29$ & $<0.001$ \\
\hline$P$ vs. controls & & $<0.01$ & $<0.001$ & $<0.001$ & \\
\hline $\mathrm{NE}+\mathrm{T}_{4}-1$ group & 10 & $0.20 \pm 0.02$ & $2.13 \pm 0.19$ & $1.93 \pm 0.18$ & $<0.001$ \\
\hline$P$ vs. controls & & $<0.001$ & $<0.001$ & $<0.001$ & \\
\hline $\mathrm{NE}+\mathrm{T}_{4}-2$ group & 5 & $0.22 \pm 0.01$ & $2.16 \pm 0.22$ & $1.94 \pm 0.22$ & $<0.001$ \\
\hline$P$ vs. controls & & $<0.001$ & $<0.001$ & $<0.001$ & \\
\hline Cold-acclimated & 12 & $0.21 \pm 0.03$ & $2.40 \pm 0.24$ & $2.20 \pm 0.22$ & $<0.001$ \\
\hline$P$ vs. controls & & $<0.001$ & $<0.001$ & $<0.001$ & \\
\hline
\end{tabular}

Means \pm S.E. of the mean, expressed as $\mu \mathrm{Eq} /(\min \cdot 100 \mathrm{~g}$ body weight $) . \quad P$ values are given in the last column for the paired difference. Each group was treated as described in the text.

Table 3. Effect of norepinephrine infusion ( $2 \mu \mathrm{g} / \mathrm{min}$ for $20 \mathrm{~min}$ ) on the ratio of oxidation to uptake rate of plasma free fatty acids (FFA) in rats treated chronically with norepinephrine $(\mathrm{NE})$ and thyroxine $\left(\mathrm{T}_{4}\right)$ under pentobarbital anesthesia.

\begin{tabular}{lccccc}
\hline & $\begin{array}{c}\text { No. } \\
\text { of rats }\end{array}$ & Before & After & $\begin{array}{c}\text { Paired } \\
\text { difference }\end{array}$ & $P$ \\
\hline Controls & 15 & $8 \pm 1$ & $32 \pm 4$ & $24 \pm 3$ & $<0.001$ \\
NE group & 12 & $8 \pm 1$ & $73 \pm 4^{*}$ & $65 \pm 4^{*}$ & $<0.001$ \\
$P$ vs. controls & & $\mathrm{N} . \mathrm{S}$. & $<0.001$ & $<0.001$ & \\
$\mathrm{~T}_{4}-1$ group & 6 & $8 \pm 1$ & $41 \pm 5$ & $33 \pm 4$ & $<0.001$ \\
$P$ vs. controls & 10 & $13 \pm 2^{*}$ & $64 \pm 5$ & $51 \pm 4$ & $<0.001$ \\
$\mathrm{~T}_{4}-2$ group & & $<0.05$ & $<0.001$ & $<0.001$ & \\
$P$ vs. controls & 10 & $8 \pm 1$ & $52 \pm 4$ & $44 \pm 4$ & $<0.001$ \\
$\mathrm{NE}+\mathrm{T}_{4}-1$ group & & $\mathrm{N} . \mathrm{S}$. & $<0.01$ & $<0.001$ & \\
$P$ vs. controls & 5 & $10 \pm 1$ & $57 \pm 5$ & $47 \pm 3$ & $<0.001$ \\
$\mathrm{NE}+\mathrm{T}_{4}$-2 group & & $\mathrm{N} . \mathrm{S}$. & $<0.01$ & $<0.001$ & \\
$P$ vs. controls & 12 & $7 \pm 1$ & $51 \pm 8$ & $44 \pm 7$ & $<0.001$ \\
Cold-acclimated & & $\mathrm{N} . \mathrm{S}$. & $<0.05$ & $<0.01$ & \\
$P$ vs. controls & & & & \\
\end{tabular}

Means \pm S.E. of the mean, expressed as $\% P$ values are given in the last column for the paired difference. $* P<0.05$ vs. cold-acclimated rats. N.S.: not significant. Each group was treated as described in the text. 
Changes in the utilization of plasma FFA during norepinephrine infusion

Changes in plasma FFA uptake by tissues are illustrated in Fig. 1. The FFA uptake significantly increased in response to norepinephrine in all groups. The FFA uptake before and after norepinephrine infusion in the $\mathrm{T}_{4}-1, N E+\mathrm{T}_{4}-1$ and cold-acclimated groups was higher than that of the controls, but there was no difference between the NE group and the controls. The oxidation rate of FFA was elevated by norepinephrine in all groups (Table 2). As shown in Table 2, the values before and after infusion of the hormone and the incremental response in the NE, $\mathrm{T}_{4}, \mathrm{NE}+\mathrm{T}_{4}$ and cold-acclimated groups were higher than those of the controls. Table 3 shows that similar fractions of plasma FFA taken up by tissues were oxidized in the state existing before norepinephrine infusion in these groups, however, there was a higher value for the $\mathrm{T}_{4}-2$ group. During norepinephrine infusion, the percentage of oxidation of FFA taken up by tissues was significantly elevated in all groups. The increase in the $\mathrm{NE}, \mathrm{T}_{4}-2$ and $\mathrm{NE}+\mathrm{T}_{4}$ groups was significantly greater than that in the controls and similar in magnitude to that in the cold-acclimated rats.

\section{Relationship between thermogenesis and FFA utilization}

The $\mathrm{CO}_{2}$ expiration rate, as an indicator of thermogenesis, increased linearly with the increase in the oxidation rate of plasma FFA in all groups. The regression coefficients did not differ among the groups, except that of the $\mathrm{T}_{4}$ group (Table 4): regression coefficients for the $T_{4}$ group were significantly smaller than those for

Table 4. Interrelationship between the oxidation rate of plasma free fatty acids

(FFA) $(X)$ and the heat production estimated as $\mathrm{CO}_{2}$ output $(Y)$ in rats treated chronically with norepinephrine $(\mathrm{NE})$ and thyroxine $\left(\mathrm{T}_{4}\right)$ under pentobarbital anesthesia.

\begin{tabular}{|c|c|c|c|c|c|c|c|}
\hline & $n$ & $\bar{X}$ & $\bar{Y}$ & $\begin{array}{l}\text { Regression } \\
\text { equation }\end{array}$ & $\begin{array}{l}\text { Regression } \\
\text { coefficient }\end{array}$ & $\begin{array}{l}\text { Correlation } \\
\text { coefficient }\end{array}$ & $P$ \\
\hline Controls & 30 & 0.47 & 32 & $Y=24 X+20$ & 24 & 0.735 & $<0.01$ \\
\hline $\begin{array}{l}\text { NE group } \\
P \text { vs. controls }\end{array}$ & 24 & 1.31 & 46 & $Y=19 X+20$ & $\begin{array}{l}19 \\
\text { N. S. }\end{array}$ & 0.830 & $<0.01$ \\
\hline $\begin{array}{l}\mathrm{T}_{4}-1 \text { group } \\
P \text { vs. controls }\end{array}$ & 12 & 1.13 & 47 & $Y=16 X+32$ & $\begin{array}{l}16 \\
<0.05\end{array}$ & 0.925 & $<0.01$ \\
\hline $\begin{array}{l}\mathrm{T}_{4}-2 \text { group } \\
P \text { vs. controls }\end{array}$ & 20 & 1.23 & 50 & $Y=13 X+34$ & $\begin{array}{l}13 \\
<0.05\end{array}$ & 0.722 & $<0.01$ \\
\hline $\begin{array}{c}\mathrm{NE}+\mathrm{T}_{4}-1 \text { group } \\
P v s . \text { controls }\end{array}$ & 20 & 1.17 & 60 & $Y=19 X+38$ & $\begin{array}{l}19 \\
\text { N. S. }\end{array}$ & 0.929 & $<0.01$ \\
\hline $\begin{array}{c}\mathrm{NE}+\mathrm{T}_{4}-2 \text { group } \\
P \text { vs. controls }\end{array}$ & 10 & 1.19 & 61 & $Y=25 X+31$ & $\begin{array}{l}25 \\
\text { N. S. }\end{array}$ & 0.972 & $<0.01$ \\
\hline $\begin{array}{l}\text { Cold-acclimated } \\
P \text { vs. controls }\end{array}$ & 24 & 1.30 & 62 & $Y=22 X+34$ & $\begin{array}{l}22 \\
\text { N. S. }\end{array}$ & 0.697 & $<0.01$ \\
\hline
\end{tabular}

$n$ : number of variables. $\bar{X}$ and $\bar{Y}$ : average of $X$ and $Y . \quad P$ values in the last column for correlation coefficient. N.S.: not significant. Each group was treated as described in the text. 
Table 5. The number and size of mitochondria in red fibers of diaphragm muscle in rats treated chronically with norepinephrine (NE) and thyroxine $\left(T_{4}\right)$.

\begin{tabular}{|c|c|c|c|c|c|c|c|}
\hline , & & $\begin{array}{c}\text { Number } \\
\text { of } \\
\text { mitochondria }\end{array}$ & $\begin{array}{l}P v s . \\
\text { controls }\end{array}$ & $\begin{array}{c}\text { Size of } \\
\text { mitochondria }\end{array}$ & $\begin{array}{l}P \text { vs. } \\
\text { controls }\end{array}$ & $\begin{array}{l}\text { Tissue } \\
\text { weight }\end{array}$ & $\begin{array}{c}P \text { vs. } \\
\text { controls }\end{array}$ \\
\hline Controls & (12) & $115 \pm 6$ & & $10.0 \pm 0.35$ & & & \\
\hline NE group & (9) & $166 \pm 8$ & $<0.001$ & $11.2 \pm 0.59$ & N.S. & $243 \pm 29$ & N.S. \\
\hline$T_{4}-2$ group & ( 7$)$ & $205 \pm 10^{*}$ & $<0.001$ & $8.5 \pm 0.55$ & $<0.05$ & $269 \pm 25$ & N. S. \\
\hline $\mathrm{NE}+\mathrm{T}_{4}-2$ group & (6) & $191 \pm 18$ & $<0.001$ & $8.3 \pm 0.63$ & $<0.02$ & $276 \pm 33$ & N. S. \\
\hline Cold-acclimated & ( 8$)$ & $168 \pm 12$ & $<0.001$ & $10.1 \pm 0.68$ & N.S. & $243 \pm 10$ & N. S. \\
\hline
\end{tabular}

Means \pm S.E. of the mean, expressed as the number of mitochondria $/ \mathrm{mm}^{2}$ of fiber, $\mu^{2}$ $\left(\times 10^{-2}\right)$ of mitochondrial area, and $\mathrm{mg}$ of diaphragm weight/100 $\mathrm{g}$ body weight. Numbers in parentheses show the number of muscle fibers used in the study. $* P<0.05$ vs. coldacclimated rats. N.S.: not significant. Each group was treated as described in the text.

the controls.

\section{Changes in the number and size of mitochondria in skeletal muscle}

As shown in Table 5, the number of mitochondria increased in the red fibers of diaphragm muscle of the NE, $\mathrm{T}_{4}-2, \mathrm{NE}+\mathrm{T}_{4}-2$ and cold-acclimated groups. The diaphragm weight did not differ among these groups. The percentage of red fibers to total fibers in diaphragm muscle was about 60 in all groups. The mean size of mitochondria was smaller in the $\mathrm{T}_{4}-2$ or $\mathrm{NE}+\mathrm{T}_{4}-2$ group than in the controls, but there was no difference between NE group or the cold-acclimated rats and the controls.

\section{DISCUSSION}

Both norepinephrine and thyroxine are essential for the production and maintenance of nonshivering thermogenesis (NST) in cold acclimation. Norepinephrine secretion is markedly stimulated in animals acutely and chronically exposed to cold (LeDUC, 1961; SHUm et al., 1969), whose thyroidal activities and peripheral deiodination of thyroxine to triiodothyronine are also increased (HÉROUX and BRAUER, 1965; SCAMMELL et al., 1980). The daily dose used in this study, norepinephrine: $70 \mu \mathrm{g} / 100 \mathrm{~g}$ body weight, thyroxine: $5 \mu \mathrm{g} / 100 \mathrm{~g}$, is close to the maximum secretion rate in cold-exposed rats (Swanson, 1957; Leduc, 1961). When norepinephrine and thyroxine were simultaneously given, similar effects on FFA utilization were induced by smaller doses than the maximum secretion of these hormones. This suggests that the hormone doses used in this study are not necessarily non-physiological.

In rats treated chronically with both norepinephrine and thyroxine, norepinephrine infusion induced a greater increase of heat production than in the controls. The incremental response to norepinephrine in heat production was also greater in the cold-acclimated rats than in the controls. It appears that the incremental heat production due to norepinephrine is a good measure of NST in cold-accli- 
mated animals. The enhanced heat production was accompanied by an increase in the FFA uptake and its oxidation in each group. The increased utilization of FFA in rats treated chronically with norepinephrine and thyroxine was characterized by a more preferential increment in the oxidation of FFA rather than by an enhanced FFA uptake (Fig. 1 and Table 2): the incremental change, under norepinephrine infusion, of FFA uptake in rats treated with norepinephrine and thyroxine did not differ from that of the controls, whereas there was a greater increase in the FFA oxidation in parallel with a more enhanced heat production induced in the former than in the latter. The findings in Table 3 support this: the percentage of FFA oxidized which had been taken up by tissues in response to norepinephrine increased more markedly in rats treated with norepinephrine and thyroxine than in the controls. From these results, it is inferred that the magnitude of the oxidation rate rather than of the rate of uptake of plasma FFA may be of direct importance in NST in rats treated with norepinephrine and thyroxine. A more preferential increase in FFA oxidation rather than in the FFA uptake, in line with a greater heat production, was also observed in the cold-acclimated rats. Thus, as far as the utilization of plasma FFA and NST are used as criteria, we were able to simulate cold acclimation in rats by treating them chronically with both norepinephrine and thyroxine. It appears that cold-acclimated rats could only partially be simulated by rats treated with norepinephrine or thyroxine alone with respect to heat production (Table 1) and percentage of oxidation of FFA taken up by tissues (Table 3).

NST increased linearly with elevations of oxidation rate of plasma FFA in all groups (Table 4). The relationship between both variables did not differ among the groups, with the exception of the $\mathrm{T}_{4}$ group in which more FFA was oxidized as energy substrate at a heat production level similar to that of other groups. However, in these groups, the maximum percent of $\mathrm{CO}_{2}$ derived from the immediate oxidation of plasma FFA remained at nearly $50 \%$ during norepinephrine infusion (unpublished data). This indicates simultaneous stimulation of oxidation of substrates other than plasma FFA. Although the percentage of FFA oxidation to total oxidative metabolism increases progressively with the passage of time after administration of ${ }^{14} \mathrm{C}$-palmitate, the increase is seemingly due to the oxidation of labeled compounds in other compartments which are not on the direct pathway of FFA oxidation. The same inference was previously gained from the study of controls and cold-acclimated rats (MORIYA et al., 1977).

Oxidation of free fatty acids occurs in mitochondria. Carnitine acyltransferase which is associated with mitochondrial membrane has been implicated as a ratelimiting step (ORAM et al., 1973). The number of mitochondria in the red fibers of diaphragm muscle was significantly greater in rats treated with norepinephrine and thyroxine and cold-acclimated rats than in the controls. The diaphragm was chosen, because skeletal muscle is one of the important thermogenic sites of NST (JANSKÝ, 1973). It is thought that the increase in NST and FFA utilization is accompanied by an increase in the number of mitochondria in skeletal muscles. In 
fact, significant increases in the number of mitochondria were demonstrated in the present study. The size of mitochondria in diaphragm muscle decreased more in rats treated with thyroxine or with both norepinephrine and thyroxine than in the controls, but there was no difference in this respect between the norepinephrinetreated or cold-acclimated rats and the controls. In rats treated with thyroxine or with both norepinephrine and thyroxine, the number of mitochondria increased by up to $70 \%$, whereas the size of mitochondria decreased by less than $20 \%$ as compared with the controls. Thus, the total mass of mitochondria in the red fibers of diaphragm muscle could be larger in rats treated with the hormones, as well as coldacclimated rats, than in the controls. In addition, the appearance of the mitochondrial cristae of these red fibers was more striking than that of the controls (unpublished data). It is thus inferred that mitochondrial activities are enhanced by chronic treatment of rats with norepinephrine and thyroxine as well as by cold acclimation.

A question arises here as to whether or not these mitochondrial changes are due primarily to an elevated respiration independent of enhanced NST. The total wet weight of diaphragm muscles remained the same in these groups (Table 5). The number of mitochondria was not necessarily related to $\mathrm{CO}_{2}$ output before norepinephrine infusion, especially in rats treated chronically with norepinephrine (Tables 1 and 5). However, possible effects of augmented respiration could not be excluded completely since physical training also increased mitochondrial numbers in skeletal muscles (GoLLNICK and KING, 1969). In cold-acclimated rats, increased numbers and decreased size of mitochondria in the semitendinosus muscle relate to mitochondrial biogenesis (HIMms-HAGEN et al., 1975). Thyroxine promotes the mitochondrial biogenesis (GUSTAFSSON et al., 1965). In the present study, chronic treatment with thyroxine as well as cold acclimation resulted in an increased number of mitochondria in the red fibers of the diaphragm. The effect of norepinephrine on mitochondrial biogenesis has not been reported. Since norepinephrine was administered in vivo in the present study, it is not obvious whether the increased number of mitochondria was induced by norepinephrine per se, or by other hormones, the secretion of which is enhanced under these conditions. The possibility that norepinephrine increases deiodination of thyroxine to triiodothyronine has been shown (GAlton, 1965; Hillier, 1968; HARDVELd et al., 1979).

The present study shows, after all, that we can simulate both biochemical and morphological changes of cold-acclimated rats by treating rats chronically with norepinephrine and thyroxine. However, we know neither the precise time course of changes in plasma levels and metabolism of the two hormones given, nor the existence of any parallelism between these changes and the actual dynamics of the hormones during cold acclimation.

\section{REFERENCES}

Galton, V.A. (1965) Thyroid hormone-catecholamine interrelationships. Endocrinology, 
77: 278-284.

Gauthier, G. F. (1977) Muscular tissue. In: Histology, ed. by WeIss, L. and Greep, R. O. McGraw-Hill Book Co., New York, pp. 251-282.

Gollnick, P. D. and KING, D. W. (1969) Effect of exercise and training on mitochondria of rat skeletal muscle. Am. J. Physiol., 216: 1502-1509.

Gustafsson, R., TAta, J. R., LindberG, O., and Ernster, L. (1965) The relationship between the structure and activity of rat skeletal muscle mitochondria after thyroidectomy and thyroid hormone treatment. J. Cell Biol., 26: 555-578.

Hardveld, C., Van Zuidwijk, M. J., and KassenaAR, A. A. H. (1979) Studies on the origin of altered thyroid hormone levels in the blood of rats during cold exposure. 1. Effect of iodine intake and food consumption. Acta Endocrinol., 91: 473-483.

Héroux, O. and Brauer, R. (1965) Critical studies on determination of thyroid secretion rate in cold-adapted animals. J. Appl. Physiol., 20: 597-606.

Hillier, A. P. (1968) Thyroxine deiodination during cold exposure in the rat. J. Physiol. (Lond.), 197: 135-147.

Himms-Hagen, J., Behrens, W., Muirhead, M., and Hbous, A. (1975) Adaptive changes in the calorigenetic effect of catecholamines: Role of changes in the adenyl cyclase system and of changes in the mitochondria. Mol. Cell Biochem., 6: 15-31.

JANSKÝ, L. (1973) Non-shivering thermogenesis and its thermoregulatory significance. Biol. Rev., 48: 85-132.

Leblanc, J. and Villemaire, A. (1970) Thyroxine and noradrenaline on noradrenaline sensitivity, cold resistance and brown fat. Am. J. Physiol., 218: 1742-1745.

LEDUC, J. (1961) Catecholamine production and release in exposure and acclimation to cold. Acta Physiol. Scand. (Suppl.), 183: 1-101.

Moriya, K., Maekubo, H., and Hiroshige, T. (1977) Effects of norepinephrine on uptake and oxidation of plasma free fatty acids in cold-acclimated rats. Jpn. J. Physiol., 27: 601-616.

Moriya, K., Maekubo, H., Honma, K., and ItoH, S. (1975) Effects of norepinephrine and thyroxine on the turnover rate of plasma free fatty acids. Jpn. J. Physiol., 25: 733-746.

OrAm, J. F., BeNNETCH, S. L., and NeELY, J. R. (1973) Regulation of fatty acids utilization in isolated perfused rat heart. J. Biol. Chem., 248: 5299-5309.

SCAMmell, J. G., Shiverick, K. T., and Fregly, M. J. (1980) In vitro hepatic deiodination of Lthyroxine to 3,5,3'-triiodothyronine in cold-acclimated rats. J. Appl. Physiol., 49: 386-389.

Shum, A., Johnson, G. E., and Flattery, K. V. (1969) Influence of ambient temperature on excretion of catecholamines and metabolites. Am. J. Physiol., 216: 1164-1169.

SWANSON, H. E. (1957) The effect of temperature on the potentiation of adrenaline by thyroxine in the albino rats. Endocrinology, 60: 205-213.

Yahata, T. and Kuroshima, A. (1977) Changes in fine structure of rat skeletal muscle related to cold acclimation. Hokkaido J. Med. Sci., 52: 63-67. 